\title{
Why Environmental Policy Nightmares Recur
}

\author{
STEVEN L. YAFFEE \\ School of Natural Resources and Environment, The University of Michigan, Ann Arbor, MI 48109-1115, U.S.A., \\ email yaffee@umich.edu
}

\begin{abstract}
Many natural resource and environmental policy issues evidence recurring choices, made with considerable effort, whose temporary solutions never seem to deal with the underlying problems. Drawing on examples from endangered species policy, I describe five behavioral tendencies of bumans and buman institutions that result in recurrent environmental policy problems, including poor long-term direction, delays, impasses, and piecemeal solutions to crosscutting problems. These tendencies are short-term rationality outcompeting long-term rationality, competitive bebavior driving out cooperative behavior, fragmentation of interests and values, fragmentation of responsibilities and autborities, and fragmentation of information and knowledge. By understanding these tendencies, it is possible to frame policy solutions to them. This paper identifies a set of necessary responses including finding ways to bind current decisionmakers to the future, promoting creativity and risk-taking on the part of public resource management organizations, utilizing alternative dispute resolution mechanisms that foster cooperation, building political concurrence, utilizing coordinating mechanisms, instituting clear performance measures, and implementing ways to promote information flows between organizations.
\end{abstract}

Por que son Recurrentes las Pesadillas en Políticas Ambientales

Resumen: Muchos aspectos de las políticas sobre recursos naturales y el ambiente evidencían decisiones recurretes realizadas con un esfuerzo considerable y cuyas soluciones temporales nunca parecen abordar problemas fundamentales. Retomando ejemplos de politicas sobre especies amenazadas, describo cinco tendencias conductuales en bumanos e instituciones humanas que terminan en recurrentes problemas relacionados con políticas ambientales, incluyendo direccion pobre a largo plazo, retrasos, detenimientos y soluciones graduales a problemas entrelazados. Estas tendencias son la competencia excesiva de racionalidad a corto plazo con racionalidad a largo plazo, conducta competitiva excluyendo la conducta cooperativa, fragmentación de intereses y valores, fragmentación de resposabilidades y autoridades y fragmentación de información y conocimiento. El entendimiento de estas tendencias permite estructurar políticas de solución para ellas. Este artículo identifica una serie de respuestas necesarias incluyendo formas para ligar a actuales tomadores de decisiones con el futuro, promover creatividad y toma de riesgos por parte de organizaciones públicas manejadoras de recursos, utilizar mecanismos alternativos que fomenten la cooperación en la solución de dísputas, construir políticas de cooperación, utilizar mecanismos de coordinación establecer medidas claras de desempeño e implementar vías para la promoción del flujo de información entre organizaciones.

\section{Introduction}

In reviewing the evolution of the Spotted Owl controversy, it is difficult not to be struck by how many opportunities existed for U. S. Forest Service (USFS) personnel to avoid the coming firestorm, yet they were unable and unwilling to do so. Although the battle over the future of

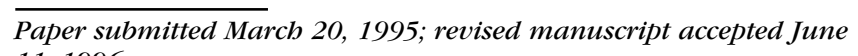
11, 1996. the old-growth forests of the Pacific Northwest appeared to leap into public view in the early 1990s, in fact administrative decisions about how to best manage habitat to protect the Northern Spotted Owl (Strix occidentalis caurina) were made some 20 years earlier. In 1973 the USFS rejected the advice of the Oregon Endangered Species Task Force that 120 ha of old growth be set aside temporarily around known owl nest sites (70 nest sites had been identified at the time) noting that setasides would "present a land management spectre of 
considerable magnitude" (Nietro undated). At least four other major administrative decision points were mishandled by the agency's leaders over the next two decades, not counting numerous ineffective internal choices, political strategies, and legal arguments, or the similar actions of many other agencies and groups (Yaffee 1994). It took intervention by President Bill Clinton in a nationally-televised forest conference in April 1993 and the subsequent creation of a Forest Ecosystem Management Assessment Team to craft a credible solution and the political will necessary for adopting it.

Agency leaders knew the owl was threatened, old growth was the issue, and changing federal forest management was necessary, but they were unable to respond effectively. They avoided learning more about the owl and its management implications, refused to focus on the underlying issue of old-growth protection and management, tried to put the issue into standard operating procedures that were not intended to deal with such issues, and aggressively sought to put off choices into the future. No doubt powerful political forces opposed effective agency action, and the stakes involved in various outcomes were extraordinarily high, but the net effect of the nature of the choices made throughout the history of the owl dispute was to embroil local, regional, and national institutions in a controversy that was much more costly than necessary.

So many environmental policy issues have a sense of déjà vu about them. "Didn't we just deal with this? Didn't we already solve this?" ask decisionmakers and the public alike. Battles over national forest plans, debates over national energy policy, and conflicts over "solving" the water problems of the arid West all represent recurring choices, made with considerable effort, whose temporary solutions never seem to deal with the underlying problems. These characteristics of environmental policy issues are repeated in public policy decisionmaking more generally, as numerous attempts to deal with the federal budget deficit attest. Substantial uncertainty is present at the core of many issues. These issues involve difficult choices, and new information and changing values require periodic adjustment of policy direction. Nevertheless, like the pattern of behavior in the owl case, it is hard to argue that the way decisions are presently made is the best we can do.

Nor does it seem to be the case that decisionmakers and decisionmaking institutions learn much from past choices and how effectively they were made or implemented. The most frightening aspect of the owl case is not that the USFS made some bad choices about not moving aggressively on owl protection in the early 1980s; rather, it is that a similar organization dealing with a comparable choice would have a good chance of making the same mistake again. Observing the USFS leaders in the late 1980s, one could sense that in their dreams they must see themselves walking down a path that never ends and that at times feels and looks exactly like their starting point.

Why do policy nightmares seem to recur? Why do choices made and behaviors carried out often lead to recurring problems needing similar choices? Although there are many ways to conceptualize the problems underlying the state of environmental policy processes today, one way is to view the situation as evidencing a set of fundamental behavioral tendencies at many levels of human social organization. Hence it is not just individuals, organizations, and decisionmaking processes that are responsible for bad decisions made in the past. Rather, it is that the choices made in cases like the Spotted Owl dispute reflect bias in the way we make decisions.

This article describes five tendencies that appear to influence individual, organizational, and institutional decisionmaking on environmental issues, and draws examples of these tendencies from several cases of endangered species policy. Concurrently, it describes the implications of these biases for forming and implementing public environmental policy and managing resource agencies. Clearly there are many other behavioral biases in human decisionmaking processes, and some of the tendencies described in this article are amalgams of other psychological or sociological dynamics. Nevertheless, the items that follow have a significant impact on the effectiveness of political and organizational decisionmaking, and by understanding them more fully policymakers and organizational leaders can counter their effects. Understanding behavioral tendencies can generate a set of policy interventions and mitigate some of the traumas that attend environmental policymaking.

\section{Five Behavioral Biases that Lead to Policy Impasses and Poor Choices}

Five key behavioral biases influenced decisionmaking in the Spotted Owl case, and there are many reasons to believe these same tendencies are evident in other policy issues.

(1) Short-term rationality outcompetes long-term rationality: a tendency to make decisions that are rational and effective in the short term, yet counterproductive and ineffective over the long term.

(2) Competitive behavior drives out cooperative behavior: a tendency to promote competitive behaviors at the expense of cooperative actions, yet often cooperation is needed to find good solutions.

(3) Fragmentation of interests and values: a proclivity to split the different elements of a society, avoiding the integration of interests and values necessary to craft effective courses of action.

(4) Fragmentation of responsibilities and authorities: a 
tendency to divide those responsible for resource management, diminishing accountability, and ensuring that management strategies are often piecemeal solutions to crosscutting problems.

(5) Fragmentation of information and knowledge: a proclivity to fragment what is known about a situation and its context so decisionmakers make bad choices because they are operating with inadequate information.

Table 1 summarizes these behavioral biases, the policy problems they create, and what is needed to check their negative effects on future environmental and natural resources decisions.

These behavioral tendencies function at all levels of social organization. Their dynamics are replicated in the behavior of individuals, groups, organizations, the policy process, and societal institutions. For example, individuals, groups, and organizations all exhibit competitive behavior as they seek to acquire and protect resources and identity. By relying on an adversarial model of decisionmaking, the policy process also is driven by competitive behavior. These tendencies also may be amalgams of more fundamental psychological, sociological, or political phenomena. For example, as discussed in the next section, the bias toward short-term rationality is underlain by a number of more fundamental tendencies, including a desire to avoid conflict and maintain control and predictability. Effective interventions must deal with some of these fundamental forces that together overemphasize short-term thinking. But as a policy matter, we can also operate directly on the overall tendency.

\section{Short-Term Versus Long-Term Rationality}

There is a general theme across many areas of human behavior in which decisionmaking that appears rational and effective in the short run turns out to be ineffective over the long term. Short-term rationality overtakes longterm rationality, and leads us to make poor choices. Hence, individuals continue to smoke and rarely save enough to cover their retirement years (unless required to do so), even though they know they would be better off doing otherwise. Variants of this dynamic have been described as the prisoner's dilemma (Luce \& Raiffa 1957) and the tragedy of the commons (Hardin 1968), in which individually rational choices lead to socially undesirable ones. Psychologists describe the tendency of individuals to rationalize past behavior and become entrapped in bad decisions (Bazerman 1986; Rubin \& Brown 1975). Heinen and Low (1992) suggest the bias toward short-term rationality has evolutionary origins. Humans evolved "to be aware only of proximate rewards and punishments, not of ultimate costs and benefits," because short-term rewards correlated well with reproductive success. Organizations seek to minimize the energy needed to respond to a situation, while maximizing control and predictability-all reasonable short-term responses-while often missing the long-term objective of solving the problem at hand or positioning the organization in a place that is more effective in the long term.

A variety of behaviors reinforce this pattern of decision making. For example, the leaders of the USFS repeatedly were overconfident in their political and technical assessments in the Spotted Owl case and tended to

Table 1. The behavioral biases that generate environmental policy problems and suggested solutions.

\begin{tabular}{|c|c|c|}
\hline Bebavioral bias & Policy problems created & Solutions \\
\hline $\begin{array}{l}\text { Short-term rationality } \\
\text { outcompetes long-term } \\
\text { rationality }\end{array}$ & poor long-term direction & $\begin{array}{l}\text { Learn about the future. } \\
\text { Bind ourselves to the future through directives, information, } \\
\text { and "fixers." } \\
\text { Promote innovation and experimentation. } \\
\text { Find creative ways to meet both short-term and long-term } \\
\text { objectives. }\end{array}$ \\
\hline $\begin{array}{l}\text { Competition supplants } \\
\text { cooperation }\end{array}$ & impasses; inferior solutions & $\begin{array}{l}\text { Develop processes that promote sharing and develop trust and } \\
\text { relationships. } \\
\text { Protect potentially exploited. } \\
\text { Focus on superordinate goals. } \\
\text { Be firm on ends; flexible on means to reach ends. }\end{array}$ \\
\hline $\begin{array}{l}\text { Fragmentation of interests } \\
\text { and values }\end{array}$ & impasses; inferior solutions & $\begin{array}{l}\text { Promote discourse and values ratification. } \\
\text { Build political concurrence. } \\
\text { Promote education of the public. }\end{array}$ \\
\hline $\begin{array}{l}\text { Fragmentation of } \\
\text { responsibilities and } \\
\text { authorities }\end{array}$ & $\begin{array}{l}\text { slow and inconclusive } \\
\text { decisionmaking; } \\
\text { diminished accountability; } \\
\text { piecemeal solutions }\end{array}$ & $\begin{array}{l}\text { Foster leadership. } \\
\text { Create coordinating mechanisms. } \\
\text { Structure incentives. } \\
\text { Develop clear measures of success and an ability to monitor } \\
\quad \text { performance. }\end{array}$ \\
\hline $\begin{array}{l}\text { Fragmentation of } \\
\text { information and } \\
\text { knowledge }\end{array}$ & inferior solutions & $\begin{array}{l}\text { Promote information flows within and between organizations. } \\
\text { Invest in better data bases. } \\
\text { Build centers of up-to-date expertise. } \\
\text { Use data negotiation. }\end{array}$ \\
\hline
\end{tabular}


only seek information that confirmed their prior conclusions. In addition, an organizational tendency to shoot the messenger of bad news, a result of the USFS's history and quasi-militaristic structure, resulted in employees filtering information as it moved upwards. Agency leaders also tried to force the owl and old-growth controversies into organizational procedures that were not effective at dealing with such controversies. These behaviors were effective for the USFS in the short term because they enabled organizational leaders to act in a controlled, fairly energy-conserving way. But they reduced the agency's fitness over time by limiting innovation and adaptation, and resulted in the top leaders becoming out of touch, making public arguments that tended to delegitimize themselves and their agency, and produced a long-term situation that was neither energy-conserving nor under control.

Many of these behavioral biases have been described in other endangered species cases. For example, internal suppression of expert opinion led to whistle-blower activities and litigation in the Red-cockaded Woodpecker (Picoides borealis) case (Jackson 1994). Reading and Miller (1994) describe the stifling of "productive dissension, resulting in reduced creativity and effectiveness" in the activities of the black-footed ferret (Mustela nigripes) recovery team. In addition, the Wyoming Game and Fish Department repeatedly downplayed the danger facing the ferret population and relied on a "business as usual" approach, even though field teams were reporting that the population was delining rapidly (Westrum 1994, 332). This behavior enabled them to protect ongoing organizational processes from disruption, but resulted in significant long-term costs. They postponed difficult choices, lost options for dealing with the situation, and caused the agency to spend much more time and energy dealing with an out of control situation than would have been necessary if they had taken on the issue in an effective way at the start. Perhaps the best example comes from the 23-year history of the Endangered Species Act (ESA) in which the U.S. Fish and Wildlife Service (USFWS) has sought to maximize organizational flexibility, avoid controversy, and offset the impacts of actions on constituent groups by delaying or not listing species-activities that often resulted in court actions that forced the agency's hand (Yaffee 1982; Coggins \& Russell 1982; Houck 1993).

Fortunately, by understanding these behavioral biases we can begin to act to moderate their effects on the choices we make as individuals and as members of larger collectivities. By putting into place mechanisms to learn about the future, it is possible to guard against some of the effects of short-term rationality. Agencies can promote longer-term thinking in several ways. They can consciously look out for changing external conditions, and do much more than has been traditionally done in scanning for new ideas and changing values.
They can engage in "double loop learning" (Argyris \& Schön 1978) in which leaders test new insights for their implications for changing organizational values and norms. Because the future is not absolutely predetermined by the past, learning about the future also involves a creative process of visioning alternative future states and "backcasting" to determine how more desirable futures may be attained.

It is also possible to try to bind ourselves to the future by forging policy instruments and processes that provide very strong incentives to consider the long term. Requiring individuals to pay into the Social Security Fund, creating federal budget targets with automatic cutbacks if action is not taken, and selecting military bases for closure by an independent commission whose results can be overturned only through major Congressional action are all mechanisms to bind decisionmakers to a long-term course of action in the face of significant short-term incentives not to do so. The ESA similarly attempts to bind decisionmakers to a course of action that makes long-term sense, but can result in short-term costs to economic objectives.

The implementation of binding policies is aided greatly by performance monitoring, with results reported to remind individuals and agencies of their obligations and to allow outside groups to "fix" implementation. Providing opportunities for groups who are likely to look out for long-run interests to be involved in decisionmaking, through advisory boards, periodic meetings, or standing to sue, can generate implementation fixers who can counter tendencies toward short-term decisionmaking (Bardach 1977).

Other responses are needed. For agencies, encouraging innovation and experimentation by allowing and rewarding risk-taking is one way to mobilize the creative ideas needed to deal with future problems. In the best of worlds, courses of action can be found that allow us to pursue short- and long-term objectives simultaneously. For example, the President's Plan in the Spotted Owl case tried to deal with short-term needs while evolving long-term action by calling for sharply reduced timber harvests and areas for creative experimentation, while providing compensation for affected interests and funds for economic diversification and job retraining (Espy \& Babbitt 1994; Wall Street Journal 1994). Similarly, the use of turtle excluder devices on Gulf Coast shrimp boats has allowed fishing while protecting endangered sea turtles (Yaffee \& Wondolleck 1994).

\section{Competition Versus Cooperation}

A second set of behavioral biases deals with the tendency of most levels of social organization to allow competitive behaviors to outcompete cooperative ones. Competitive behaviors involve a win-lose model of hu- 
man decisionmaking, where the gains of one party imply losses to another (Lax \& Sebenius 1986). Competitive behaviors include strategic misrepresentation by individuals and groups, battles between organizations over turf, and the tendency of decisionmaking processes such as adversarial judicial processes to polarize the positions of disputants. Cooperative behaviors assume a win-win decisionmaking model, where the gains of one party might not be achieved at the expense of another party. Cooperative behaviors include sharing of information, joint management of common property resources in a way that shares budget and other rewards, and collaborative decisionmaking processes that seek to satisfy (at least minimally) all parties' concerns.

Competitive behavior leads to a variety of policy problems. In a system of fragmented power with many avenues for influencing policy choices, sustained competition leads to the kind of impasses evident through much of the later history of the owl case. Impasses may simply cause delay with benefits to certain interests, but they often simultaneously chew up a significant amount of societal resources. In the owl case impasses were not in the interest of most parties because old growth was increasingly fragmented, reducing options for environmentalists, while the scientific base for expanded protection increased, reducing the power of the timber interests. For the agencies impasses put other resource management objectives on hold and contributed to a decline in technical legitimacy and agency morale.

Competitive behaviors also lead to poor quality decisions. Problem-solving that is effective over the long run can only result from a process that is as informed about present and future needs as is possible, but competitive behavior often leads individuals to misrepresent and bias information. In the owl case interest groups overstated the realities of their information in the media, and agency leaders knowingly misrepresented information for strategic purposes (Yaffee 1994). Similarly, the California Condor (Gymnogyps californianus) recovery team's 1985 position rejecting releases of condors back into the wild was "turned around 180 degrees" by USFWS administrators and presented as an endorsement of the USFWS position recommending releases. The recovery team's position was also misrepresented to the National Audubon Society board by staff members anxious to gain board support for their position (Snyder 1994: 190).

The literature on negotiation argues that joint gainssituations where all parties to a dispute can benefit-can be achieved via processes that promote shared information and collaborative problem-solving, whereas competitive processes will miss the opportunity to find such gains (Lax \& Sebenius 1986). But Bazerman (1986: 128131) argues that a fundamental cognitive bias in individuals is the "myth of the fixed pie," that is, that individuals assume their interests directly conflict with those of others and that their gains can only come at a cost to others. When faced with a zero sum, fixed pie situation, the only rational behavior is to compete for the largest share of the pie. As a result, competition dominates situations that may not be zero sum, and overly competitive behaviors lead to inferior solutions so policymakers must continue to revisit the same issues.

There are several ways to manage the dynamic of competition overtaking cooperation. One set deals with developing decisionmaking and management processes that promote sharing of information and develop trust and relationships between disputing parties to promote collaborative problem-solving. Such approaches have been defined as so-called alternative dispute resolution processes, many of which employ nonpartisan, thirdparty facilitators to guide the disputants toward a more cooperative mode of resolving their differences (Bingham 1986; Carpenter \& Kennedy 1988; Susskind \& Cruikshank 1987; Wondolleck 1988). In creating such processes there is always the potential that underpowered parties will be exploited by more powerful ones, so it is important to institute ways to protect potentially-exploited interests. Creating normative bottom lines, such as the ESA's mandate that species not be allowed to go extinct, or vesting guardianship of interests (such as those of future generations) in an agency or a nongovernmental organization can help to mitigate the potential for underpowered parties to be exploited.

One way out of the impasses created by excessive competition is to find ways to have conflicting interests focus on superordinate goals, that is, objectives that they share that are above the level of the current dispute (Pruitt \& Rubin 1986). Hence, most of the groups involved in the owl conflict agree that both endangered species protection and economic stability are important goals, but when the dialogue pits one way to pursue one objective against one way to pursue another, the disputants are often stuck with strategic posturing between mutually-exclusive options.

Finding ways that all interests can be firm about the ends they seek, yet flexible about the means to reach those ends, would help us get out of the traps caused by the competition-cooperation bind. Rarely are the ultimate objectives of groups mutually exclusive, whereas the positions they stake out may be. For example, the Grayrocks Dam near Wheatland, Wyoming is often cited as a win-win situation, in which negotiation based on interests rather than positions allowed the project to proceed. Minimum water flows were guaranteed, and a trust fund was created to purchase water rights and additional habitat to protect the endangered Whooping Crane (Grus americana). Research funded by the trust fund has generated new information about the crane and several other endangered species (Yaffee \& Wondolleck 1994). In a similar situation, negotiations over a proposed residential development on San Bruno Mountain 
near San Francisco resulted in permanent habitat protection for three endangered butterflies and allowed residential development in $10 \%$ of the butterflies' habitat (Yaffee \& Wondolleck 1994).

\section{Fragmentation of Interests and Values}

The remaining three behavioral tendencies deal with the proclivity of individuals, groups, and decisionmaking processes to break things apart, and hold them apart, when effective decisionmaking requires integration. Fragmentation of interests and values is evident at all levels of social organization. It results from the raw diversity of ideas and groups in American society, a political process that disperses power across numerous interests, and a set of societal institutions that are not very effective at promoting integration across the diverse interests and conflicting values present in a pluralistic society.

Political fragmentation has increased in recent years as interest group politics have become dominant (Berry 1989). Battles over endangered species conservation do not just pit environmentalists against loggers or developers; rather, a diversity of groups on both sides are involved, and the growth of the so-called wise use movement and the rebirth of local environmental groups promises to increase this diversity. To survive, interest groups must carve out a niche and defend it. Because any ultimate solution to a policy issue is a balance between the differing positions, it makes sense for groups to argue for the extremes, in order to get a course of action somewhere in the middle. But both of these behaviors tend to break apart the spectrum of interests and values and make it difficult for effective social choices to be made.

Groups also tend to exaggerate the differences between them, often unfairly ascribing malignant intent to the actions of each other. Hence, environmentalists become radical, anti-growth preservationists, and timber interests become uncaring, profit-hungry forest rapists. The overspecification of differences between groups is productive in the short run, by offering individuals a sense of identity and belonging, and simplifying a situation by stereotyping the behavior of other groups. But it also tends to split important groups from each otherenvironmentalists from timber groups, local groups from national organizations, agency scientists from managers-in ways that are counterproductive over the long term.

Political fragmentation is supported by the fragmentation of interests and values in individuals. Where once social institutions such as churches and political parties helped individuals build holistic images across a set of issues (even if they were backwards-seeking images), the decline of these institutions (Putnam 1996), the rise of interest groups, and the explosion in the number and type of information sources have tended to allow individuals to hold onto conflicting values and not be forced to make trade-offs between them. For example, at both individual and societal levels, there is clearly a fragmentation of values around environmental objectives. Individuals can simultaneously value old-growth trees as a component of an unharvested forest, and the lovely, clear wood that is produced from such trees as components of framing lumber and finished wood products. Large majorities of surveyed individuals value environmental and endangered species protection even at the cost of economic growth, yet identify the economy as their top-ranked concern (Hueber 1991; Greenberg/Lake memo to The Nature Conservancy \& the National Audubon Society on bipartisan poll results, 1992; Gallup 1992).

The result is that many conflicts persist because an integration of these choices and values is not made or forced by decisionmaking processes. Not once did the groups involved in the owl controversy collectively face the real policy issue: how can we protect important environmental values in the Pacific Northwest, including the old-growth ecosystem, while building sustainable economies that support the needs of current and future humans? Decisions were focused on various statutorilydefined questions that were much narrower than an effective problem-solving process warranted. The multiplicity of decision points provided by a fragmented policy process allowed groups to press their case repeatedly on different grounds-forest management, endangered species, environmental impact, administrative procedures-and appeal choices first to higher administrative authorities, then to the courts and Congress.

The net effect of these dynamics is that they create impasses and poor quality decisions. Fragmented political power also limits the will of elected officials to take action because they will be attacked by one side or the other. Above all else, politicians seek to adopt stands that are already well supported across the voting public. Fragmentation of interests and values diminishes their ability to do so.

There are several ways out of the dilemmas caused by fragmentation of interests and values. Creating processes that promote discourse between those who hold different interests and values can help to build shared understanding of what is at stake. These kinds of processes also can help to shatter the stereotyped images that groups form of each other, leading to more effective problem-solving. Such processes might include round table discussions, town meetings, computer networks, and video conferences, as well as facilitated policy dialogues and dispute-related negotiations. Generating decisionmaking approaches and opportunities for individual learning that force people to ratify what values they hold, and the trades they would make between them, would also help a great deal. 
Using a variety of mechanisms to build political concurrence across a fragmented interest landscape can also help to overcome the decisionmaking impotence created by a fragmentation of interests and values. For example, the federal and state agencies need to build a new coalition of support for updated resource management by reaching out to the diversity of parties that value natural resources, using the media and working the political landscape aggressively. Educational approaches that forge understanding of different interests and values in both formal (K-12 and colleges) and nonformal (community, midcareer professional) settings are also helpful to overcome the problems caused by fragmentation.

\section{Fragmentation of Responsibilities and Authorities}

Another behavioral bias that affects many areas of resource and environmental policy is a tendency toward fragmented responsibility and authority in the ways collective choices are made and implemented. In public land management fragmented authorities are defined partly by geographic fragmentation, where land ownership across a contiguous and interconnected landscape is shared by millions of individual decisionmakers. Resource management also evidences functional and decisionmaking fragmentation. For example, while the USFS manages habitat within the boundaries of a national forest, the USFWS regulates populations of endangered species, and state governments control wildlife populations. Numerous Congressional committees have partial interest in the activities occurring on federal lands, with significant policy duplication occurring between authorizing and appropriations committees.

Fragmentation of responsibilities and authorities is not just a historical artifact. It is sought by individuals and groups, partly because it limits the liability involved in making decisions. If everyone is partially in charge, then no one is truly in charge. In the owl case, when faced with demands for altered timber management policies, the USFS and the BLM could point to Congress and say the timber bias of on-the-ground management was their fault. Members of Congress on authorizing committees could say that they had provided the National Forest Management Act-process to sort out these kinds of issues and it was the appropriations committees that messed things up. Appropriations could say that the agencies had never said that they could not carry out high timber cut levels without causing serious environmental damage. The ultimate result of this pattern of behavior was that no one had to take the responsibility for a difficult choice.

Fragmentation is also promoted by the tendency of individuals, groups, and organizations to seek turf and build niches for themselves. Often their turf-seeking be- havior becomes an overriding goal and damages efforts that require cooperation. Such "goal inversion"-where organizational goals dominate and often override conservation goals-has been seen in studies of the grizzly bear (Grumbine 1992), the Spotted Owl (Yaffee 1994), the gray wolf (Houck 1993), and the great whales (Kellert 1986). It has also been well documented in recovery efforts for the black-footed ferret (Clark \& Harvey 1988).

As a policy matter fragmentation of responsibilities and authorities leads to several problems. At minimum, the multiplicity of players with marginal authority and interconnected decisionmaking guarantees that decisionmaking will be slow and generally inconclusive. The diminished accountability that results from fragmented responsibility means that a lot of important decisions fall through the cracks between responsible parties. Fragmented responsibilities and authorities also generate piecemeal solutions that might make sense on the agency level, but make no sense on the societal level.

The black-footed ferret provides a classic case in which efforts by one agency-the Wyoming Game and Fish Department (WGF)-to maintain their turf promoted fragmentation and hampered recovery efforts. For example, WGF staff hampered captive breeding efforts in part because "they feared loss of control" if ferrets were released to facilities in other states (Reading \& Miller 1994, 85). The WGF would not sign the recovery plan unless its representative chaired the committee that coordinated the breeding program (Crowe, memo from Wyoming Game \& Fish Dept. to USFWS, March 1, 1988). Other groups were forced to sign agreements giving WGF ultimate control over protocols and animals in their facilities (Reading \& Miller 1994). The WGF delayed reintroduction efforts in Montana and limited research efforts over which they had little control. They also controlled interactions between researchers and local people, resulting in program delays, distrust, and poor relations between involved organizations and hampered recovery efforts (Reading \& Miller 1994).

The effects of fragmented responsibilities and authorities can be overcome in several ways. Strong, articulate leadership can be a powerful integrating force, though there are considerable forces against it in today's society (Yaffee 1994). Creating a variety of coordinating mechanisms can help to bridge fragmented authorities and create relationships that might offset the tendency towards fragmentation. Such mechanisms might include ecosystem-level multiparty policy councils, interagency management teams, revitalized regional planning bodies, and information clearinghouses. It is important that such initiatives provide incentives to member groups to be actively involved. Such incentives might consist of a substantive mandate that can only be achieved through cooperative efforts, or new resources controlled by the coordinating group. Having federal agency budgets appropriated to interagency ecosystem-level teams for 
later distribution to member agencies would do wonders at making the agencies notice the teams.

Having clear, shared measures of success and ways to monitor progress toward desired ends are other ways to guard against the problems of fragmented responsibilities. In public land management, creating clear measures of success might mean overlaying a dominant use framework on top of a fragmented landscape, so federal lands are allocated to conservation or commodity production purposes. Or it might mean grafting superordinate objectives on existing agency mandates, so the protection and restoration of ecological integrity is established as a top priority. Whatever objectives are created, finding effective ways to measure performance towards those objectives will help check some of the tendencies toward diminished accountability and provide an impetus for focusing on solving the problem, rather than simply taking fragmented action.

\section{Fragmentation of Information and Knowledge}

A final behavioral bias that creates policy problems is the fragmentation of information and knowledge. Information and understanding are fragmented between professional disciplines, economic sectors (public, private, etc.), levels of government, agencies, organizations, and social grouping. For example, through much of the owl controversy, a substantial amount of information was available about the owl, its habitat needs, and the state of the old-growth forest, but much of it was scattered across numerous offices and groups. Getting an image of the forest, rather than the trees, was very difficult. Information about forest cover existed largely on paper, scattered in numerous USFS, Bureau of Land Management (BLM), and state offices in different formats. Although some of this information was accurate and up-to-date, much was inaccurate and outdated, making the problem of integrating information even more difficult.

Fragmentation of information is reinforced by several behavioral factors. Because information is collected in response to specific needs, it is generally biased to past problems and reflects specific organizational contexts. Hence, if the mission of the USFS is to maximize timber production, collecting information on a stand-by-stand basis in a form that allows planners to compute volume and lay out sales makes sense. But the information this mode of information collection provides is unlikely to help determine how much ecologically-significant old growth exists in western Oregon and Washington.

Because the objectives and problems faced by various agencies differ, the information they collect is often not helpful to each other, even if they were inclined to share it. And information-sharing is limited by the attitudes of individuals and groups toward each other. In the owl case, the researchers and the managers, the environmen- tal groups and the USFS, and the USFS and the USFWS did not trust each other, and these intergroup attitudes tended to make each protective of their own information or deny the credibility of the other's information (Yaffee 1994). In recovery efforts for the Yellowstone grizzly bear (Ursus arctos borribilis) population, agency researchers were not willing to consult with other experts and resisted incorporating the work of nonagency scientists in evaluating habitat. According to Mattson and Craighead (1994: 113), this fragmentation of expertise was part of a pattern of behavior that resulted in "gross distortion of basic biological knowledge."

Information is power, particularly in an information age, and that means there are behavioral reasons to not share information, to suppress it directly, and to not seek disconfirming information. Hence, researchers do not share their data until it is published in a way that guarantees ownership, agencies do not share their information, and interest groups do not reveal their information until it can be used to strategic advantage in a courtroom or legislative process. The fact that it took more than 16 years after the need for a credible map of old growth was recognized for one to be assembled by the USFS suggests the behavioral dimensions of information. At first, agency officials did not view it as important, then they did not want to know the answer, and finally, they viewed such a map as not to their strategic advantage. Although this behavior might have felt functional for the agency and its leaders, it led to consistent policy problems: poor quality decisionmaking and advocacy science leading to impasses.

There are ways out of the dilemma posed by the fragmentation of information and knowledge. Better mechanisms for sharing information within and between organizations are needed, including shared geographic information systems, information clearinghouses, and the like. Because information is almost always biased toward past uses and objectives, it is important to create databases organized for collecting basic information that can be utilized in ways that are currently unforeseen, as problems emerge and conditions change. Other needed solutions include building up-to-date local centers of expertise, with strong incentives and ability to link outward to other regions, agencies, and societies. Creating opportunities and incentives for data negotiation, that is, debate and discussion between conflicting sources of expertise, can help bound the range of uncertainty that decisionmakers face when confronted by multiple and conflicting sources of information.

\section{Challenges in Overcoming Biases}

The solution to all of these behavioral biases is some measure of integration between the needs of the present and the future, competitive and cooperative behaviors, 
differing interests and values, dispersed responsibilities and authority, and information and knowledge. Crafting solutions to these problems is difficult because these behavioral biases exist, at least somewhat, for good reasons. Although short-term decisionmaking dooms us in the long run, it is much more likely that we can assess courses of action that are effective and rational in the short run than predict what will happen in the future. Intervening events and changes in technology and values, among other things, will influence the future in ways we cannot foresee, and many planned interventions in the past have failed precisely because of this inability to forecast.

There are benefits to other behavioral biases as well. Although competitive behavior might diminish the potential for disputants to find joint gains, competition is a desirable way to promote the honing of skills and abilities at the individual, organizational, and societal levels. This dynamic can be seen across a wide range of human and nonhuman activities, including athletics, business, and evolutionary biology. It is a good idea to have agencies competing for resources and participants in markets competing for market share. Both tend to promote efficiencies and relevance to human needs.

Similarly, there is wisdom in fragmentation. Diversity yields long-term societal fitness. It allows for the testing of different ideas and promotes learning at the margins of groups. Intergroup conflict is the basic engine of social change, and hence at times, it should be valued, not minimized. Dispersed power is also a benefit, just as it was when the U.S. was founded. It provides checks and balances on excessive control by one faction, yet allows legitimate interests to be expressed if they can amass enough power to be heard. Although this last feature can suppress minority concerns, it does provide a testing ground for the significance of a given concern.

It is also the case that the alternatives, while desirable for many reasons, are not costless. Long-term thinking, cooperation, integration across interests, authorities, and knowledge all take time and energy. For example, although interagency cooperation is an innocuous term, as a practical matter, it involves staff members going to meetings and writing reports that may not appear to contribute to the core mission of their agencies. If coordination affects on-the-ground action, it may mean that one agency has to change its behavior to conform to the needs of the larger group. To the agency cooperation may mean a loss of control and autonomy with effects on organizational morale and mission.

In crafting solutions to get around these problematic behavioral characteristics, it is important to keep the attractive features of these biases and the costs of alternatives in mind. We should seek an integration of these concerns, meaning that both are considered, not a replacement of one by the other. For example, there are ways to manage the competition-cooperation issue that promote communication and joint management while maintaining the "honing" aspects of competitive behavior. In public land management creating organizational superstructures such as ecosystem-level coordinating bodies who administer grant programs can foster cooperation, while maintaining a diversity of agencies who compete for resources and carry out activities in their own styles. A mix of cooperation and competition can best generate effective public policies, while diminishing the potential for impasses and poor decisions. The task of crafting behavior-sensitive policy is not easy, nor is there a single solution. Instead, a continued process of experimentation, monitoring and evaluation, and informed change, is most likely to overcome the behavioral problems of natural resource policies and institutions.

\section{Crafting Behavior-Sensitive Policies}

All indications are that the need to be sensitive to underlying behavioral tendencies will be heightened by the conditions of our near-term future. An increasing rate of change will make the long term come to us faster. It will be necessary to work harder at anticipating likely change, and avoiding impasses that consume valuable time. As resources become appropriated more completely and environments evidence more stress, declining slack in the natural resource base will cause short-term actions to have more impact on options and increase the costs of bad choices. The globalization of economies and cultures will generate heightened interdependency and increase the number of authorities dealing with common problems. Greater diversity in policymaking settings will tend to further fragment interests and values, while the costs of unproductive competition will increase as weaponry proliferates. Rising interdependency and diversity create an unprecedented need for cooperation and efforts to bridge fragmented interests. Finally, the amount and dispersion of information will increase, resulting in a greater likelihood that knowledge will be fragmented, in spite of extraordinary technology to help out.

The existence of consistent behavioral tendencies underlying environmental policy problems also suggests the need for policy scientists to revise their conceptualizations of the policy process. Policy models are still largely grounded in an economic model of human rationality, yet it is clear that a variety of behavioral dynamics take place in decisionmaking. An integration of the perspectives yielded by psychological, sociological, organizational, political, and economic models of behavior is needed so that proposed policy interventions are more likely to deal with the problems at hand.

It should not be surprising that a set of problematic human behavioral tendencies underlie many natural resource and environmental policy problems. Human behavior is the source of most environmental problems; 
hence, the resolution of these problems involves influencing this behavior. Fortunately, by understanding some of the behavioral tendencies of individuals, groups, organizations, decisionmaking processes, and societies as they influence environmental policy, decisionmakers can frame appropriate policy interventions. Natural resource policymakers must understand this because otherwise their actions will be doomed to failure, and they will re-live policy nightmares. Creative resource management strategies that do not consider the human dynamics implicit in such strategies will not succeed. As in the long history of decisionmaking in the Spotted Owl controversy, they waste social resources and cost us time in dealing with the very serious set of problems that face all lifeforms in the near-term future.

\section{Literature Cited}

Argyris, C., and D. A. Schon. 1978. Organizational learning: a theory of action perspective. Addison-Wesley, Reading, Massachusetts.

Bardach, E. 1977. The implementation game: what happens after a bill becomes a law. MIT Press, Cambridge, Massachusetts.

Bazerman, M. H. 1986. Judgment in managerial decision making. John Wiley, New York.

Berry, J. M. 1989. The interest group society. 2nd edition. Scott, Foresman, Glenview, Illinois.

Bingham, G. 1986. Resolving environmental disputes: a decade of experience. The Conservation Foundation, Washington, D.C.

Carpenter, S. L., and W. J. D. Kennedy. 1988. Managing public disputes. Jossey-Bass, San Francisco.

Clark, T. W., and A. H. Harvey. 1988. Implementing endangered species recovery policy: learning as we go? Endangered Species Update 5:35-42.

Coggins, G., and I. Russell. 1982. Beyond shooting snail darters in pork barrels: endangered species and land use in America. Georgetown Law Journal 70:1433-1525.

Espy, M., and B. Babbitt. 1994. Record of decision for amendment to Forest Service and Bureau of Land Management planning documents within the range of the Northern Spotted Owl. U.S. Forest Service and U.S. Bureau of Land Management, Portland, Oregon.

Gallup, Jr., G. 1992. The Gallup poll: public opinion 1991. Scholarly Resources, Wilmington, Delaware.

Grumbine, R. E. 1992. Ghost bears: exploring the biodiversity crisis. Island Press, Washington, D.C.

Hardin, G. 1968. The tragedy of the commons. Science 162:1243-1248.

Heinen, J. T., and B. S. Low. 1992. Human behavioral ecology and environmental conservation. Environmental Conservation 19:105-116.

Houck, O. A. 1993. The Endangered Species Act and its implementation by the U.S. Departments of Interior and Commerce. University of Colorado Law Review 64:278-369.

Hueber, G. 1991. Americans report high levels of environmental concern, activity. The Gallup poll monthly, no. 307.

Jackson, J. A. 1994. The Red-cockaded Woodpecker recovery pro- gram: professional obstacles to cooperation. Pages 157-181 in T. W. Clark, R. P. Reading, and A. L. Clarke, editors. Endangered species recovery: finding the lessons, improving the process. Island Press, Washington, D.C.

Kellert, S. R. 1986. Marine mammals, endangered species, and intergovernmental relations. In M. Silva, editor. Ocean resources and U.S. governmental relations in the 1980s. Westview Press, Boulder, Colorado.

Lax, D. A., and J. K. Sebenius. 1986. The manager as negotiator: bargaining for cooperation and competitive gain. Free Press, New York.

Luce, R. D., and H. Raiffa. 1957. Games and decisions: introduction and critical survey. John Wiley, New York.

Mattson, D. J., and J. J. Craighead. 1994. The Yellowstone grizzly bear recovery program: uncertain information, uncertain policy. Pages 101-129 in T. W. Clark, R. P. Reading, and A. L. Clarke, editors. Endangered species recovery: finding the lessons, improving the process. Island Press, Washington, D.C.

Nietro, B. undated. Chronology of events related to the Spotted Owl issue. U.S. Bureau of Land Management Oregon State Office, Portland, Oregon.

Pruitt, D. G., and J. Z. Rubin. 1986. Social conflict: escalation, stalemate, and settlement. Random House, New York.

Putnam, R. 1996. Bowling alone: America's declining social capital. Journal of Democracy 6:65-78.

Reading, R. P., and B. J. Miller. 1994. The black-footed ferret recovery program: unmasking professional and organizational weaknesses. Pages 73-100 in T. W. Clark, R. P. Reading, and A. L. Clarke, editors. Endangered species recovery: finding the lessons, improving the process. Island Press, Washington, D.C.

Rubin, J. Z., and B. Brown. 1975. The social psychology of bargaining and negotiation. Academic Press, New York.

Snyder, N. F. R. 1994. The California condor recovery program: problems in organization and execution. Pages 183-204 in T. W. Clark, R. P. Reading, and A. L. Clarke, editors. Endangered species recovery: finding the lessons, improving the process. Island Press, Washington, D.C.

Susskind, L., and J. Cruikshank. 1987. Breaking the impasse: consensual approaches to resolving public disputes. Basic Books, New York.

Wall Street Journal. 1994. Clinton officials tighten plan for Northwest forests. February 24:C19.

Westrum, R. 1994. An organizational perspective: designing recovery teams from the inside out. Pages 327-349 in T. W. Clark, R. P. Reading, and A. L. Clarke, editors. Endangered species recovery: finding the lessons, improving the process. Island Press, Washington, D.C.

Wondolleck, J. M. 1988. Public lands conflict and resolution: managing national forest disputes. Plenum, New York.

Yaffee, S. L. 1982. Prohibitive policy: implementing the federal Endangered Species Act. MIT Press, Cambridge, Massachusetts.

Yaffee, S. L. 1994. The wisdom of the Spotted Owl: policy lessons for a new century. Island Press, Washington, D.C.

Yaffee, S. L., and J. M. Wondolleck. 1994. Negotiating survival: an assessment of the potential use of alternative dispute resolution techniques for resolving conflicts between endangered species and development. School of Natural Resources and Environment, The University of Michigan, Ann Arbor. 